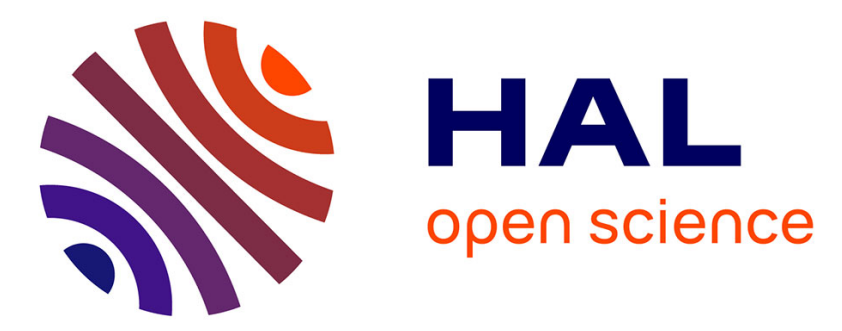

\title{
Spatially controlled DNA unzipping by microfluidic interface positioning on a molecule perpendicular to a multicomponent flow
}

\author{
Naresh K Mani, Sergii Rudiuk, Damien Baigl
}

\section{- To cite this version:}

Naresh K Mani, Sergii Rudiuk, Damien Baigl. Spatially controlled DNA unzipping by microfluidic interface positioning on a molecule perpendicular to a multicomponent flow. Chemical Communications, 2013, 49 (61), pp.6858. 10.1039/c3cc44016h . hal-02368943

HAL Id: hal-02368943

https://hal.science/hal-02368943

Submitted on 21 Nov 2019

HAL is a multi-disciplinary open access archive for the deposit and dissemination of scientific research documents, whether they are published or not. The documents may come from teaching and research institutions in France or abroad, or from public or private research centers.
L'archive ouverte pluridisciplinaire HAL, est destinée au dépôt et à la diffusion de documents scientifiques de niveau recherche, publiés ou non, émanant des établissements d'enseignement et de recherche français ou étrangers, des laboratoires publics ou privés. 


\title{
Spatially controlled DNA unzipping by microfluidic interface positioning on a molecule perpendicular to a multicomponent flow $\dagger$
}

\author{
Naresh K. Mani, ${ }^{a, b, c}$ Sergii Rudiuk ${ }^{a, b, c}$ and Damien Baigl ${ }^{a, b, c}$ \\ Received (in XXX, XXX) Xth XXXXXXXXX 20XX, Accepted Xth XXXXXXXXX 20XX \\ DOI: 10.1039/b000000x
}

\begin{abstract}
A DNA molecule is rotated under a transversal electric field to be perpendicular to a longitudinal, multicomponent microfluidic flow. Positioning the interface allows us to control DNA unzipping with spatio-temporal resolution. This 10 demonstrates that a microfluidic gradient can be applied at the single molecule level for a dynamic intramolecular stimulation.
\end{abstract}

Due to the important roles of molecular gradients in biological and synthetic systems, efforts have been devoted for the 15 realization of controlled gradients at a microscale. The development of numerous microfluidic tools ${ }^{1,2}$ has enabled the creation and fine control of molecular gradients via diffusionbased and/or flow-based approaches. ${ }^{3}$ Microfluidics-based gradient devices have been successfully used to modulate or 20 control various biological processes, such as cell migration, ${ }^{4}$ stem cells differentiation, ${ }^{5}$ axon guidance, ${ }^{6}$ and embryonic development. ${ }^{7}$ Microfluidic gradients have also been applied at a single cell level. For instance, a seminal demonstration was reported by Takayama et al. who succeeded to deliver 25 small molecules into selected domains inside an individual cell by a partial treatment using a laminar multicomponent flow. ${ }^{8}$ However, to our knowledge, microfluidic gradients have never been applied to create a controlled perturbation at a single-molecule level. In this communication, we describe 30 the application of electric field for positioning a single DNA molecule perpendicularly to a longitudinal, multicomponent microfluidic flow in order to control its unzipping, i.e. intramolecular denaturation, with spatio-temporal resolution. The application of electric fields to manipulate DNA 35 molecules in nano- or microfluidic channels has been widely used for applications such as DNA stretching,,${ }^{9,10}$ separation, ${ }^{11-15}$ concentration, ${ }^{16}$ mapping ${ }^{17-19}$ or polymer physics investigations. $^{20-25}$ Contrary to these classical approaches, where DNA molecules are usually stretched in 40 the same direction as that of the microfluidic flow, here we applied the electric field to rotate a single DNA molecule, orthogonally to a multicomponent microfluidic laminar flow composed of a buffer phase and a denaturant phase.

Figure 1A shows our experimental set-up. It consisted in a 45 microfluidic device having two inlets for creating a laminar flow with two components : a DNA buffer solution (upper phase) and a denaturating solution (lower phase). Under our experimental conditions, the Peclet number varied between 50 and 100 (S.I., Table 1), which ensured a steep profile of so denaturating agent concentration around the interface position. To apply an electric field perpendicular to the flow, two electrodes were inserted in reservoirs situating at both ends of another channel (vertical channel in Fig. 1A) perpendicular to the main channel. Finally, a single DNA 55 molecule was tethered on a $10 \mu \mathrm{m}$ diameter pillar, placed at the crossing region.

A)

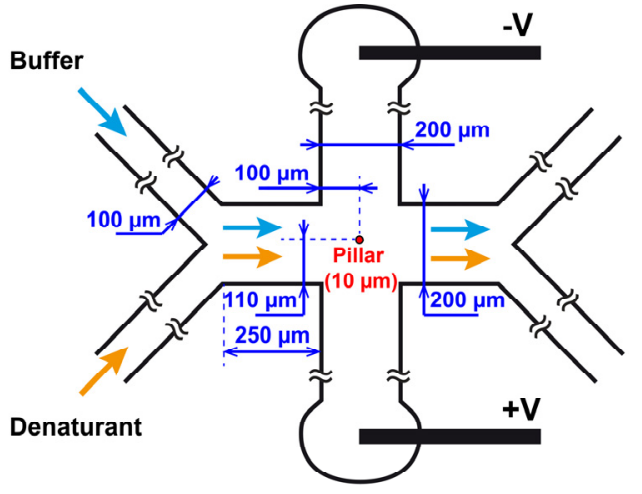

B)

1) Electrophoretic DNA rotation in a longitudinal flow

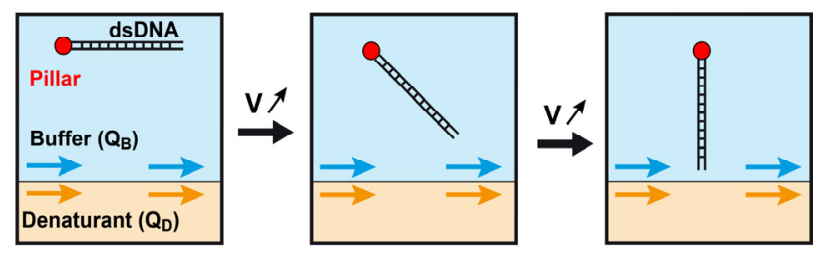

2) Intramolecular denaturation control by interface positioning

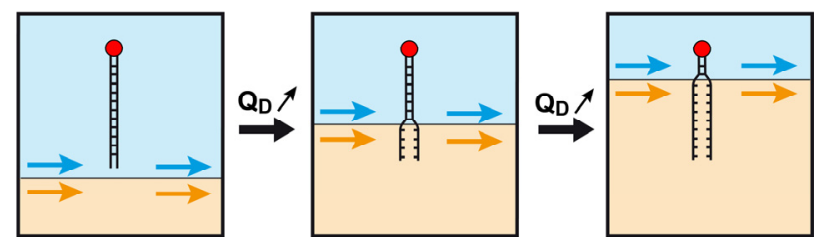

60 Figure 1. Experimental set-up and concept. A) A microfluidic device, made of PDMS, contains two inlets (one for a DNA buffer solution, another one for a denaturant solution), one main channel and two outlets. The main channel is crossed by another channel, along which an electric field is generated from two electrodes. A single pillar (10 $\mu \mathrm{m}$ in diameter) is at the crossing region. All channels are $7.5 \mu \mathrm{m}$ high. B) A monobiotinylated doubled-stranded DNA (dsDNA) is attached to the 
streptavidinated pillar in the absence of electric field. The electric field is increased to bring the DNA molecule perpendicular to the flow axis (1). Increasing the denaturant flow rate allows to maintain the interface at different positions of the molecule, thus unzipping DNA in a spatiotemporally controlled fashion (2).

Our strategy for intra-molecular control of DNA unzipping is shown in Fig. 1B. First, in the absence of electric field and denaturating phase flow $\left(Q_{D}=0\right)$, a double-stranded DNA molecule (dsDNA) was tethered to the pillar by streptavidin10 biotin binding. Then, constant flows of DNA buffer $\left(Q_{B} \neq 0\right)$ and denaturing phase $\left(Q_{D} \neq 0\right)$ were applied to keep the interface far from the pillar while stretching the DNA molecule along the flow (Fig. 1B, top left). Then, the application of an increasing electric field gradually rotated 15 DNA (Fig. 1B, top middle) until an angle close to $90^{\circ}$ when the electrostatic attraction created by the electric field overcame the longitudinal force created by the flow (Fig. 1B, top right). The electric field was then kept constant and the increase in $Q_{D}$ allowed us to maintain the interface at different ${ }_{20}$ positions, thus inducing a partial DNA denaturation, or unzipping, when a steep denaturant concentration gradient was created along the DNA molecule (Fig. 1B, bottom).

\section{A)}

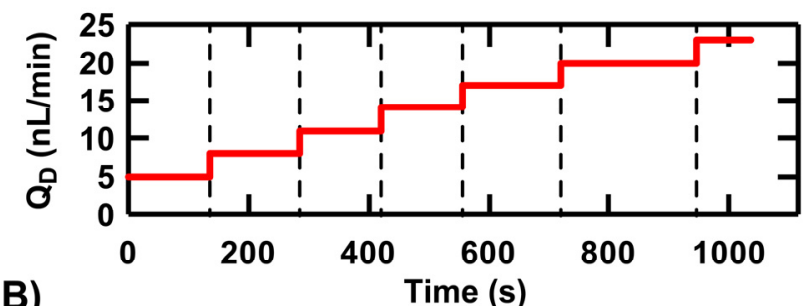

B)

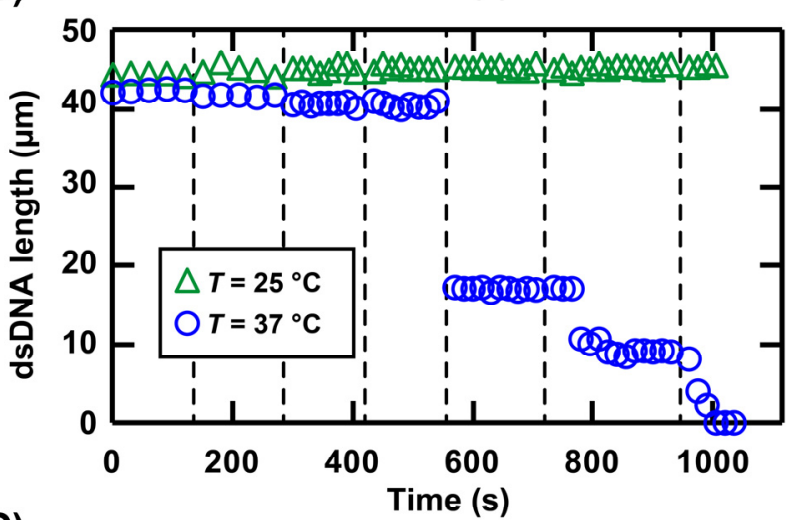

C)

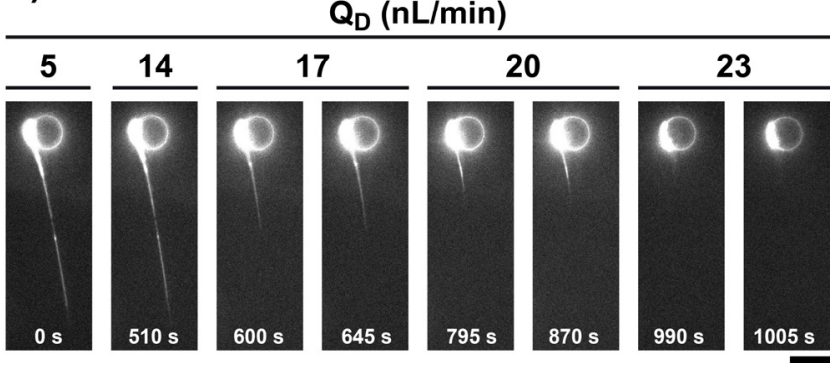

Figure 2. DNA unzipping by microfluidic interface positioning. A) Flow rate of the denaturant phase $\left(Q_{D}\right)$ as a function of time. The flow rate of the buffer phase $\left(Q_{B}=50 \mathrm{~nL} / \mathrm{min}\right)$ and the electric field (400
$\mathrm{V} / \mathrm{cm}$ ) are fixed. B) Length of a dsDNA molecule as a function of time 30 under non-denaturating $\left(T=25^{\circ} \mathrm{C}\right.$, green triangles) and denaturating ( $T$ $=37^{\circ} \mathrm{C}$, blue circles) conditions. C) Fluorescence microscopy images of the DNA molecule in denaturating conditions as a function of time. Scale bar is $10 \mu \mathrm{m}$.

The intramolecular unzipping experiment was performed as 35 follows. First, the PDMS surface of the microfluidic channel was covalently covered with streptavidin prior to bonding to a PDMS-coated microscopy glass slide (see S.I., Materials and Methods for details). The device was then filled with a 0.3 $\mu \mathrm{M}$ solution of monobiotinylated $\lambda \mathrm{DNA}$ concatemers $(3$ 40 copies of $\lambda$ DNA per molecule, i.e. 145,500 base pairs, in average) in a buffer composed of $10 \times$ Tris-EDTA and YOYO1 DNA fluorescent dye $(60 \mathrm{nM})$. At this step, the conjugation led to one or several concatemers bound to the pillar and the experiment was continued only in the former case. After DNA 45 binding to the pillar, the flow rate of the DNA buffer solution was fixed at $Q_{B}=50 \mathrm{~nL} / \mathrm{min}$. Then, the denaturant solution $(89 \% \mathrm{~V} / \mathrm{V}$ formamide in $10 \times$ Tris-EDTA) was added into the microfluidic device at a starting flow rate of $Q_{D}=5 \mathrm{~nL} / \mathrm{min}$. An electric field of $400 \mathrm{~V} / \mathrm{cm}$ was applied to rotate DNA. ${ }_{50}$ Under these conditions, DNA could be maintained almost perpendicular to the flow in the whole range of investigated flow rates. Lower electric fields led to smaller angles with respect to the flow direction while much higher fields induced DNA breakage or detachment from the pillar.

${ }_{55}$ We applied a stepwise increase in $Q_{D}$ (Fig. 2A) and DNA was observed by fluorescence microscopy. Since YOYO-1 is an intercalator that specifically dyes double-stranded, non denaturated part of DNA, we characterized the course of local DNA denaturation, or unzipping, by measuring the length of 60 the fluorescent dsDNA part (Figs. 2B-C). A first experiment was performed at $37^{\circ} \mathrm{C}$, a temperature at which DNA is fully denaturated in a $89 \% \mathrm{~V} / \mathrm{V}$ formamide solution. Figure 2 shows that for each denaturant flow rate, dsDNA reached rapidly a stable length that could be maintained as long as the ${ }_{65}$ flow rate was not changed. For the lower flow rates, a slight decrease in the time-average dsDNA length was observed (from $42.2 \pm 0.2 \mu \mathrm{m}$ to $40.4 \pm 0.4 \mu \mathrm{m}$ ) with an increase in $Q_{D}$ from $5 \mathrm{~nL} / \mathrm{min}$ to $14 \mathrm{~nL} / \mathrm{min}$. In this regime of $Q_{D}$, the interface remained too far from DNA to induce significant 70 denaturation. Interestingly, a strong and stepwise decrease in dsDNA length $(17.0 \pm 0.2 \mu \mathrm{m}$ and $9.4 \pm 0.8 \mu \mathrm{m})$ was observed with a further increase in $Q_{D}(17 \mathrm{~nL} / \mathrm{min}$ and $20 \mathrm{~nL} / \mathrm{min}$, respectivey). Under these conditions, it was thus possible to maintain a single DNA molecule in different partially 75 denaturated states, thanks to the local gradient of formamide along the concatemer. For higher flow rates $\left(Q_{D} \geq 23 \mathrm{~nL} / \mathrm{min}\right)$, dsDNA could not be distinguished anymore, which was attributed to full denaturation by formamide. To be sure that the extinction of YOYO-1 fluorescence was due to local 80 denaturation, we performed a control experiment at $25{ }^{\circ} \mathrm{C}$, a temperature at which DNA is not denaturated in a $89 \% \mathrm{~V} / \mathrm{V}$ formamide solution. Fig. 2B (green triangles) shows that the whole concatemer remained fluorescent for the whole range of flow rates. This shows that DNA can be observed in both 85 formamide and buffer solutions but only when it is doublestranded. Therefore, the decrease in dsDNA length observed at $37^{\circ} \mathrm{C}$ (denaturating conditions) is unambiguously attributed 
to the partial DNA unzipping.

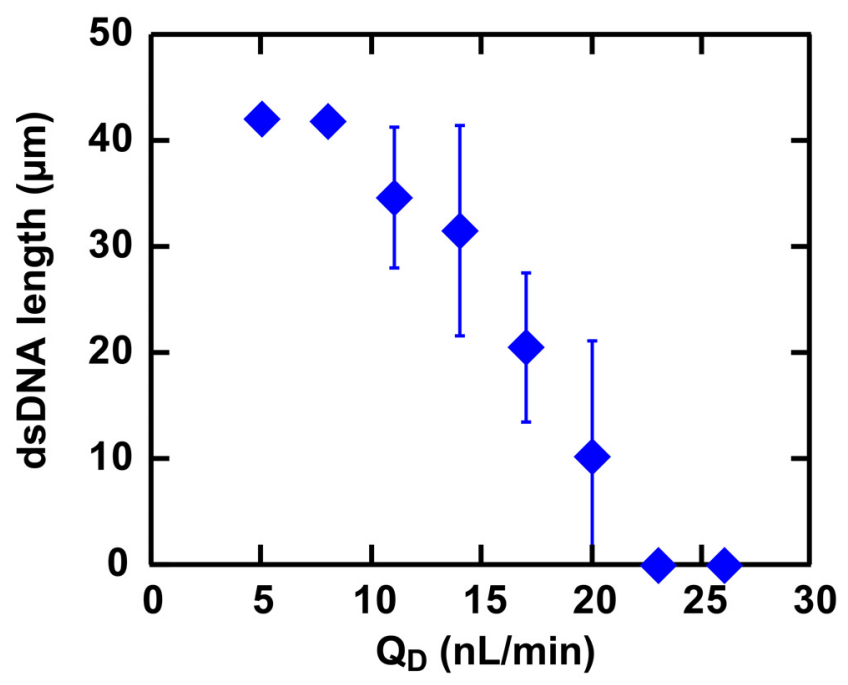

Figure 3. Length of dsDNA molecule as function of the denaturant flow rate $\left(Q_{D}\right)$. The flow rate of the buffer phase $\left(Q_{B}=50 \mathrm{~nL} / \mathrm{min}\right)$ and the electric field $(400 \mathrm{~V} / \mathrm{cm})$ are fixed. Symbols and error bars show mean values $\pm \mathrm{SD}$ from triplicates. Error bars are not shown when they are smaller than the symbol size. $\mathrm{T}=37^{\circ} \mathrm{C}$.

We then investigated how DNA unzipping could be spatially controlled by positionning the buffer/denaturant interface. Figure 3 shows the average dsDNA length as a function of $Q_{D}$ on triplicate experiments. Although a 15 significant variability between experiments was observed, three features were reproducibly observed. At a low $Q_{D}$, the formamide flow was localized far from DNA and no denaturation was observed. Conversely, at a high $Q_{D}$, full denaturation was always achieved. Interestingly, in the 20 intermediate range of $Q_{D}$ values, dsDNA length significantly decreased with an increase in $Q_{D}$ due to the successive positions of buffer/denaturant interface that progressed across the DNA molecule.

We described a microfluidic device in which a single DNA 25 molecule was electrostatically maintained perpendicular to a multicomponent flow composed of buffer and denaturing solutions. We showed for the first time that a simple control of the solution flow rates allowed us to move the buffer/denaturant interface at different positions across the 30 DNA molecule, resulting in successive, stable, partially denaturated states. This concept of intramolecular control by microfluidic interface positionning, demonstrated here with a simple unzipping process, could be extended to other chemical or biochemical intramolecular stimulations (e.g., 35 compaction agents, enzymes) for a broad range of fundamental or practical chemical, biophysical or biotechnological applications.

\section{Notes and references}

${ }^{a}$ Department of Chemistry, Ecole Normale Supérieure, 75005 Paris, France

${ }^{b}$ Université Pierre et Marie Curie - Paris 6, 75005 Paris, France $45^{c}$ UMR 8640, CNRS, France.

* Corresponding author e-mail: damien.baigl@ens.fr; website: http://www.baigllab.com/; phone: +33 144322405.

$\dagger$ Electronic Supplementary Information (ESI) available: Materials and methods, Table S1. See DOI: 10.1039/b000000x/

50

1. N. L. Jeon, S. K. W. Dertinger, D. T. Chiu, I. S. Choi, A. D. Stroock, and G. M. Whitesides, Langmuir, 2000, 16, 8311-8316.

2. S. K. W. Dertinger, D. T. Chiu, N. L. Jeon, and G. M. Whitesides, Anal. Chem., 2001, 73, 1240-1246.

55 3. S. Kim, H. J. Kim, and N. L. Jeon, Integr. Biol., 2010, 2, 584-603.

4. N. Li Jeon, H. Baskaran, S. K. W. Dertinger, G. M. Whitesides, L. Van de Water, and M. Toner, Nat. Biotechnol., 2002, 20, 826-830.

5. B. G. Chung, L. a Flanagan, S. W. Rhee, P. H. Schwartz, A. P. Lee, E. S. Monuki, and N. L. Jeon, Lab Chip, 2005, 5, 401-406.

606 . S. K. W. Dertinger, X. Jiang, Z. Li, V. N. Murthy, and G. M. Whitesides, Proc. Natl. Acad. Sci. U. S. A., 2002, 99, 12542-12547.

7. E. M. Lucchetta, J. H. Lee, L. A. Fu, N. H. Patel, and R. F. Ismagilov, Nature, 2005, 434, 1134-1138.

8. S. Takayama, E. Ostuni, P. LeDuc, K. Naruse, D. E. Ingber, and G. M. Whitesides, Nature, 2001, 411, 1016.

9. S. Ferree and H. W. Blanch, Biophys. J., 2003, 85, 2539-2546.

10. G. C. Randall, K. M. Schultz, and P. S. Doyle, Lab Chip, 2006, 6, $516-525$.

11. J. Han and H. G. Craighead, Science, 2000, 288, 1026-1029.

70 12. P. S. Doyle, J. Bibette, A. Bancaud, and J.-L. Viovy, Science, 2002, 295, 2237.

13. N. Kaji, Y. Tezuka, Y. Takamura, M. Ueda, T. Nishimoto, H. Nakanishi, Y. Horiike, and Y. Baba, Anal. Chem., 2004, 76, 15-22.

14. N. Nazemifard, S. Bhattacharjee, J. H. Masliyah, and D. J. Harrison, Angew. Chem. Int. Ed., 2010, 49, 3326-3329.

15. T. Yasui, N. Kaji, R. Ogawa, S. Hashioka, M. Tokeshi, Y. Horiike, and Y. Baba, Anal. Chem., 2011, 83, 6635-6640.

16. D. Stein, Z. Deurvorst, F. H. J. van der Heyden, W. J. a Koopmans, A. Gabel, and C. Dekker, Nano Lett., 2010, 10, 765-772.

80 17. R. Riehn, M. Lu, Y.-M. Wang, S. F. Lim, E. C. Cox, and R. H. Austin, Proc. Natl. Acad. Sci. U. S. A., 2005, 102, 10012-10016.

18. B. R. Cipriany, R. Zhao, P. J. Murphy, S. L. Levy, C. P. Tan, H. G. Craighead, and P. D. Soloway, Anal. Chem., 2010, 82, 2480-2187.

19. W. Reisner, N. B. Larsen, A. Silahtaroglu, A. Kristensen, N. Tommerup, J. O. Tegenfeldt, and H. Flyvbjerg, Proc. Natl. Acad. Sci. U. S. A., 2010, 107, 13294-13299.

20. J. J. Jones, J. R. C. van der Maarel, and P. S. Doyle, Phys. Rev. Lett., 2013, 110, 068101.

21. J. Wang and C. Lu, J. Appl. Phys., 2007, 102, 074703.

90 22. C. Zhang, P. G. Shao, J. a van Kan, and J. R. C. van der Maarel, Proc. Natl. Acad. Sci. U. S. A., 2009, 106, 16651-16656.

23. C. Zhou, W. W. Reisner, R. J. Staunton, A. Ashan, R. H. Austin, and R. Riehn, Phys. Rev. Lett., 2011, 106, 248103.

24. A. G. Balducci, J. Tang, and P. S. Doyle, Macromolecules, 2008, 41, 9914-9918.

25. J.-W. Yeh, A. Taloni, Y.-L. Chen, and C.-F. Chou, Nano Lett., 2012, 12, 1597-602. 


\section{Supporting information for:}

\section{Spatially controlled DNA unzipping by microfluidic}

\section{interface positioning on a molecule perpendicular to a}

\section{multicomponent flow}

Naresh K. Mani, ${ }^{a, b, c}$ Sergii Rudiuk ${ }^{a, b, c}$ and Damien Baigl*a,b,c

${ }^{a}$ Department of Chemistry, Ecole Normale Supérieure, 75005 Paris, France

${ }^{b}$ Université Pierre et Marie Curie - Paris 6, 75005 Paris, France

${ }^{c}$ UMR 8640, CNRS, France

* Corresponding author e-mail: damien.baigl@ens.fr; website: http://www.baigllab.com/; phone: +3314432 2405 .

\section{$\underline{\text { Contents }}$}

1. Material and Methods

2. Table S1

3. Supplementary Reference 


\section{Materials and Methods}

\section{Materials}

$\lambda$ DNA $(390 \mu \mathrm{g} / \mathrm{mL}), 100 \times$ Tris-EDTA buffer solution ( $\mathrm{pH} \mathrm{8),} \mathrm{3-(Aminopropyl)} \mathrm{triethoxy}$ silane (APTES), trimethylchlorosilane (TMCS), glutaraldehyde ( $8 \%$ in water) and formamide were purchased from Sigma. Streptavidin was purchased from Life Technologies. $12 \mathrm{nt}$ single-stranded oligonucleotide 5'-GGGCGGCGACCT-3' biotinylated via a TEG linker at 3' position and complementary to one of the sticky ends of $\lambda$ DNA was purchased from Eurogentec. T4 DNA ligase solution $(350 \mathrm{U} / \mu \mathrm{L})$ and 10x ligase buffer were purchased from Takara. Unless specified, all other chemicals were from Sigma.

\section{Microfluidic device fabrication}

\section{Mask Patterning}

The mask pattern was designed using L-edit and generated using $\mu \mathrm{PG} 101$ Laser writing system (Heidelberg instruments) on the optical masks coated with $1000 \AA$ thick chrome and 1 $\mu \mathrm{m}$ thick AZ 1518 positive photoresist (Nanofilm, CIPEC company). The optical mask was then developed for $1 \mathrm{~min}$ in MIF-726 positive developer (Microchemicals Company), and after rinsing with MQ water, the chrome metal layer was etched for $1 \mathrm{~min}$ in Chrome-Etch 3144 (Honeywell). The mask was then rinsed again with MQ water and dried.

\section{Soft lithography}

To achieve proper spatial resolution, we used an improved soft lithography method by performing the usual photolithography steps (resist coating, insulation, and development) directly on the front surface of mask. First, an adhesion layer (Omnicoat) was coated on the mask and baked at $200^{\circ} \mathrm{C}$ for $1 \mathrm{~min}$. Negative photoresist SU8 2005 (Clariant) was then spin coated to achieve a thickness of $7.5 \mu \mathrm{m}$ followed by soft baking at $65^{\circ} \mathrm{C}$ and $95^{\circ} \mathrm{C}$ for $1 \mathrm{~min}$ and $2 \mathrm{~min}$, respectively. The coated mask was then exposed to UV using MJB4 aligner (Süss MicroTec), and baked again at $65^{\circ} \mathrm{C}$ and $95^{\circ} \mathrm{C}$ for $1 \mathrm{~min}$ and $2 \mathrm{~min}$, respectively. Finally, after the development of the resist in SU8 developer for $1 \mathrm{~min}$, the obtained mold was rinsed with isopropyl alcohol, dried and treated with trimethylchlorosilane (TMCS) vapor for $5 \mathrm{~min}$. 


\section{PDMS chip fabrication}

The polydimethysiloxane PDMS (RTV 615, GE Toshiba Silicones Co., Ltd.) was prepared by mixing base-polymer and cross-linker at 10:1 ratio. It was then poured onto the mold, degassed under the vacuum and cured at $80^{\circ} \mathrm{C}$ overnight.

\section{PDMS surface modification}

Preparation of PDMS-APTES solid substrate

PDMS chip was removed from the mold, rinsed with absolute ethanol and dried using pressurized air. The PDMS surface was then activated by air plasma at 300 - 400 mTorr for 3 min (Plasma cleaner, Harrick), and treated for $10 \mathrm{~min}$ with 10\% (v/v) solution of 3Aminopropyl-triethoxysilane (APTES) in absolute ethanol. The APTES-treated PDMS was then rinsed with $96 \%$ ethanol, dried, and baked at $125^{\circ} \mathrm{C}$ for $30 \mathrm{~min}$.

Immobilization of streptavidin on PDMS

APTES treated surface was then treated with glutaraldehyde solution ( $8 \%$ in water) for 1 hour at room temperature, carefully rinsed using MQ water and dried by pressurized air. The crosslinking of streptavidin on PDMS surface was then achieved by incubating the glutaraldehyde-treated PDMS surface with streptavidin water solution $(0.1 \mathrm{mg} / \mathrm{mL})$ for 2 hours. The streptavidin-treated PDMS surface was then rinsed twice using MQ water and finally dried using pressurized air.

\section{Bonding glass substrate and streptavidin-coated PDMS}

The cover slips (Menzel-Glaser, $24 \mathrm{~mm}$ wide, $60 \mathrm{~mm}$ long, 0.13-0.16 mm thick) were cleaned with absolute ethanol and spin coated with PDMS (10:1). After baking at $125^{\circ} \mathrm{C}$ for $10 \mathrm{~min}$, the cover slips were treated with air plasma for $3 \mathrm{~min}$ at $300-400 \mathrm{mTorr}$ and assembled with streptavidin-coated PDMS chip. Liquid PDMS was then applied all along the contact line between the chip and the PDMS-coated cover slip, prior to baking at $50{ }^{\circ} \mathrm{C}$ for $15 \mathrm{~min}$. 


\section{Preparation of monobiotinylated $\lambda$ DNA concatemers}

$50 \mu \mathrm{L}$ of $\lambda$ DNA (48.5 kbp) stock solution $\left(390 \mu \mathrm{g} / \mathrm{mL}\right.$ ) was incubated at $65{ }^{\circ} \mathrm{C}$ for $5 \mathrm{~min}$ prior to cooling in ice for $5 \mathrm{~min}$. $\lambda \mathrm{DNA}$ concatemers were prepared by adding to the icecooled mix of $\lambda \mathrm{DNA}, 4 \mu \mathrm{L}$ of T4 DNA ligase (Takara $350 \mathrm{U} / \mu \mathrm{L}$ ) and $6 \mu \mathrm{L}$ of $10 \times$ ligase buffer (Takara) at $16{ }^{\circ} \mathrm{C}$ for 5 hours. To bind biotin at one end of thus obtained $\lambda$ DNA concatemers, $0.6 \mu \mathrm{L}$ of diluted 3'-biotinylated single-stranded oligonucleotide $(4.48 \mu \mathrm{g} / \mathrm{mL})$ complementary to one of the sticky ends of $\lambda$ DNA was added to the $\lambda$ DNA concatemers solution $(325 \mu \mathrm{g} / \mathrm{mL})$ to give a $\lambda \mathrm{DNA}$ :oligonucleotide molecular ratio of $1: 1$. After adding an additional amount of $4 \mu \mathrm{L}$ of T4 DNA ligase, the mix was incubated again at $16{ }^{\circ} \mathrm{C}$ for overnight. This procedure led to the preparation of monobiotinylated concatemers having mainly 3 copies of $\lambda$ DNA.

\section{DNA unzipping experiment}

First, the microfluidic device with closed outlets was filled via Tygon tubing using syringe pump (Harvard apparatus) at $3000 \mathrm{~nL} / \mathrm{min}$ with DNA-buffer solution containing $\lambda$ DNA concatemers $(0.3 \mu \mathrm{M}$ in nucleotides), YOYO-1 fluorescent dye $(0.06 \mu \mathrm{M})$ and mercaptoethanol $(1 \% \mathrm{~V} / \mathrm{V})$ in Tris-EDTA buffer $(10 \times)$. This led to the binding of individual DNA concatemers to the pillar of the device. Two Pt electrodes were then inserted in their respective reservoirs, and DNA-buffer flow rate was decreased to $Q_{B}=50 \mathrm{~nL} / \mathrm{min}$. After the equilibration of the buffer flow, the denaturant flow, containing formamide $(89 \% \mathrm{~V} / \mathrm{V})$, TrisEDTA buffer $(10 \times)$, rhodamine B $(10 \mu \mathrm{M})$ and mercaptoethanol $(1 \% \mathrm{~V} / \mathrm{V})$, was set at $Q_{D}=5$ $\mathrm{nL} / \mathrm{min}$. The electric field (400 V/cm, Labsmith high voltage sequence wizard) was then applied to rotate DNA attached to the pillar perpendicularly to the flow. The denaturant $\left(Q_{D}\right)$ flow rate was then increased stepwise at a fixed DNA-buffer flow rate $\left(Q_{B}=50 \mathrm{~nL} / \mathrm{min}\right)$, and the length of double-stranded DNA was monitored by fluorescence microscopy (YOYO-1 fluorescence). Rhodamine B fluorescence was used to check the position of the interface.

\section{Fluorescence microscopy}

Fluorescence microscopy was performed with an AxioObserver D1 inverted microscope (Zeiss), equipped with a $100 \times$ oil immersion objective lens. Images were acquired with a 
highly sensitive EMCCD camera (Photonmax 512B, Princeton Scientific) and Metavue image acquisition software (Molecular Devices). 


\section{Supplementary Table}

Table S1. Estimation of the Peclet $(P e)$ number range under our experimental conditions. Pe was calculated as $P e=Q /(h D)$ where $Q, h$, and $D$ where the flow rate, the channel height and the diffusion coefficient, respectively. Minimal and maximal flow rates $(Q)$ were 50 and $80 \mathrm{~nL} / \mathrm{min}$, respectively. The values of the diffusion coefficient of formamide in water $(D)$ at $25^{\circ} \mathrm{C}$ and $37^{\circ} \mathrm{C}$ were taken from literature. ${ }^{1}$

\begin{tabular}{|c|c|c|c|}
\hline $\boldsymbol{Q}(\mathbf{n L} / \mathbf{m i n})$ & $\boldsymbol{T}\left({ }^{\circ} \mathbf{C}\right)$ & $\boldsymbol{D}\left(\mathbf{m}^{\mathbf{2}} / \mathbf{s}\right)$ & $\boldsymbol{P e}$ \\
\hline 50 & 25 & $1.72 \times 10^{-9}$ & 64.6 \\
\hline 50 & 37 & $2.20 \times 10^{-9}$ & 50.5 \\
\hline 80 & 25 & $1.72 \times 10^{-9}$ & 103 \\
\hline 80 & 37 & $2.20 \times 10^{-9}$ & 80.8 \\
\hline
\end{tabular}




\section{Supplementary Reference}

1. C. M. Gary-Bobo and H. W. Weber, J. Phys. Chem., 1969, 73, 1155-1156 